\title{
TROPOSPHERIC OZONE IN THE CZECH REPUBLIC, 1994-2000
}

\section{M.-H. TSHIAMALA MBUYI}

Received: 21/08/01

Accepted: 01/04/02
Instistute of Landscape Ecology

Mendel University of Agriculture and Forestry Brno

Zěmědelská 1, 61300 Brno, Chech Republic

e-mail:melhene@yahoo.com

\begin{abstract}
Air pollution is changing the ecosystems, especially in Europe. Tropospheric ozone may adversely affect tree growth, with critical levels for ozone being exceeded in many parts of Europe, especially in the Czech Republic. This research reports the information on exceedances of ozone threshold values for the period 1994 to 2000 and gives an evaluation of the observed exceedances of the thresholds during the vegetation period (April-September) and from May to July at the Bílý Kříž station. The threshold for warning of the public ( $240 \mu \mathrm{g} \mathrm{m}^{-3}$ as hourly average concentration) was not exceeded at the Bílý Kř́žz station for the studied period. The threshold value for information to the population $\left(180 \mu \mathrm{g} \mathrm{m}^{-3}\right.$ as hourly average concentration) was exceeded in 1994 (July and August), 1995 (May and July), 1998 (August) and 2000 (June). The threshold value set for the protection of human health population (120 $\mu \mathrm{g} \mathrm{m}^{-3}$ as eight-hourly average concentration) was exceeded for all period at the Bílý Kříz station.
\end{abstract}

KEYWORDS: annual concentration, Bílý Křriž station, daily value, eight-hour value, one-hour value, exceedances, tropospheric ozone

\section{INTRODUCTION}

Ozone is a natural constituent of the atmosphere with a vital role in many atmospheric processes (Hjellbrekke, 2000). While ozone in the stratosphere has beneficial role, the ozone close to the plantet's surface, in the region known as the troposphere, displays a destructive side. Because it reacts strongly with other molecules, it severaly damages the living tissue of plants and animals. It is one of key pollutants in "smog" that hangs over many cities around the world. However, man made emissions of volatile organic compounds and nitrogen oxides have influenced the production of tropospheric ozone (EEA, 1997; Beck et al., 1998; Matyssek and Innes, 1999; Hjellbrekke, 2000; Hůnová et al., 2000). Of this various different types of air pollutants currently impacting for- est in the Czech Republic, the greatest concern surrounds ozone (Rožnovský and Blažek, 1996; Hůnová et al., 2000; Pelikán et al., 2000; Svoboda, 2000; De Leeuw et al., 1999, 2000; Hjellbrekke, 2000; Tshiamala and Rožnovský, 2000a, b, c). Tropospheric ozone, a major air pollutant in industrialised countries (Matyssek and Innes, 1999; Jackson et al., 2000; Polle et al., 2000), is transported across national boundaries (EEA, 1998).

Ozone is a strong photochemical oxidant which may cause serious health problems and damage to materials and ecosystems (Andreani-Aksoyoglu, 1996; Rožnovský and Blažek, 1996; Matyssek and Innes, 1999; De Leeuw et al., 1999, 2000; Polle et al., 2000). Ozone in the troposphere has also of relevance to the climate change issue since it is a 
greenhouse gas (EEA, 1998). Emissions of nitrogen oxides $\left(\mathrm{NO}_{\mathrm{x}}\right)$ are responsible for much of the ozone formation occurring in rural areas (EEA, 1998; Matyssek and Innes, 1999). Tropospheric ozone is a secondary pollutant formed by photochemical reaction of primary pollutants known as precursors (nitrogen oxides: $\mathrm{NO}_{\mathrm{x}}$, carbon monoxide: $\mathrm{CO}$, volatile organic compounds: VOCs) in the presence of sunlight. Since weather conditions (sunshine, high temperatures and low winds) have an important part in the formation of ozone, pollution episodes occur mainly in summer, in urban, periurban and rural areas.

Human exposure to elevated levels of ozone concentrations can give rise to inflammatory responses and decreases in lung function (Fally et al., 1995; APPA, 1998; De Leeuw et al., 1999, 2000). Ozone exposure of ecosystems and agricultural crops results in invisible foliar injury and in reductions in crop yield and seed production, and loss in forest productivity (Fally et al., 1995; Rožnovský and Blažek, 1996; Matyssek and Innes, 1999; De Leeuw et al., 2000; Jackson et al., 2000; Polle et al., 2000). Threshold values set for the protection of human health, vegetation and ecosystems are exceeded frequently in most cities (and stations) of the Czech Republic and therefore widespread adverse effects on the Czech population, crops and natural vegetation may be expected (Hůnová et al., 2000; Svoboda, 2000; Tshiamala and Rožnovský, 2000a, b, c).

Ozone concentrations vary widely from region to region, with the time of year, and with time of day. Typically, high concentrations of ozone are observed in periods with anticyclonic conditions (Hjellbrekke, 2000). National authorities and international organisations have therefore formulated critical levels for ozone. According to the European Union ozone directive No 0068/99/EC, the threshold values for protection of human health are $120 \mu \mathrm{g} \mathrm{m}^{-3}$ for eight-hourly mean and for the protection of material $40 \mu \mathrm{g} \mathrm{m}^{-3}$ for annual mean. In addition, information should be given to the population when hourly means exceed $180 \mu \mathrm{g} \mathrm{m}^{-3}$ and a warning should be issued if hourly mean exceeds the $240 \mu \mathrm{g} \mathrm{m}^{-3}$. This Directive about the air pollution by ozone aims to establish a harminised procedure in the European Union for monitoring, exchanging information, and informing and warning the population.

\section{MATERIALS AND METHODS}

The Czech Hydrometeorological Institute has its regional offices in all the former regional capitals, which are mainly concerned with measurements, data collection and initial processing within their respective regions. The ozone concentration measurement is based on ultraviolet absorption photometry, by UV analyser fy Te Instruments, model 49. The presented method with automatic pressure and temperature compensation meets the challenging requirements for ozone measurement.

The assessment of air pollution by ozone in the region of Beskids was based on observation of Automated Monitoring Station (AMS) from $1^{\text {st }}$ March 1994 to $31^{\text {th }}$ December 2000 at Bílý Kříž. These results are selected on measurements at the experimental ecological station Bílý Kříž at $49^{\circ} 30^{\prime} 17^{\prime \prime}$ northern latitude and $18^{\circ} 32^{\prime} 28^{\prime \prime}$ eastern longitude. This station is located at an altitude of $908 \mathrm{~m}$ in the region of Beskids, at the eastern part of the Czech Republic. The region of the Beskids, especially Bílý Krríž, is about 30 to $40 \mathrm{~km}$ from important emission sources in the regions of Karviná and Ostrava.

The assessment of the state of ambient air pollution is based on air pollution standards set down by the new directives of European Union. Assessment of the status of the air pollution is based on air pollution standards as specified by new European directives published on 22 April 1999 No. 0068/99 for tropospheric ozone and is based on Czech standards for ozone.

\section{RESULTS AND DISCUSSION}

Short-term ( 1 hour) and prolonged ( 8 hours) exposures to ambient ozone have been linked to a number of health effects of concern. The longterm (e.g. 3 months, 6 months, one year) of ozone exposure affects vegetation and ecosystems, reduces the plant growth, increases the plant susceptibility to diseasse.

\section{Hour values of ozone}

The ambient air pollution hourly limit value of ozone for human information is $180 \mu \mathrm{g} \mathrm{m}^{-3}$. At the Bílý Kříž station, the one-hour values of ozone concentration were ranged between 11.0 and $210.0 \mu \mathrm{g} \mathrm{m}^{-3}$ for 1994 to 2000 (Fig. 1) and numbered 18 days and 80 hours when this limit was exceeded (Table 1). The highest hour mean val- 
Table 1. Occurence of exceedances of one-hour limit of $180 \mu \mathrm{g} \mathrm{m}^{-3}$ (a) and $200 \mu \mathrm{g} \mathrm{m}^{-3}$ (b) for 1994 to 2000.

\begin{tabular}{|c|c|c|c|c|}
\hline Year & days (a) & hours (a) & days (b) & hours (b) \\
\hline 1994 & 8 & 42 & 4 & 4 \\
\hline 1995 & 8 & 30 & 2 & 2 \\
\hline 1996 & 0 & - & - & - \\
\hline 1997 & 0 & - & - & - \\
\hline 1998 & 1 & 5 & - & - \\
\hline 1999 & 0 & - & - & - \\
\hline 2000 & 1 & 3 & $\mathbf{6}$ & $\mathbf{6}$ \\
\hline Sum & $\mathbf{1 8}$ & $\mathbf{8 0}$ & & - \\
\hline
\end{tabular}

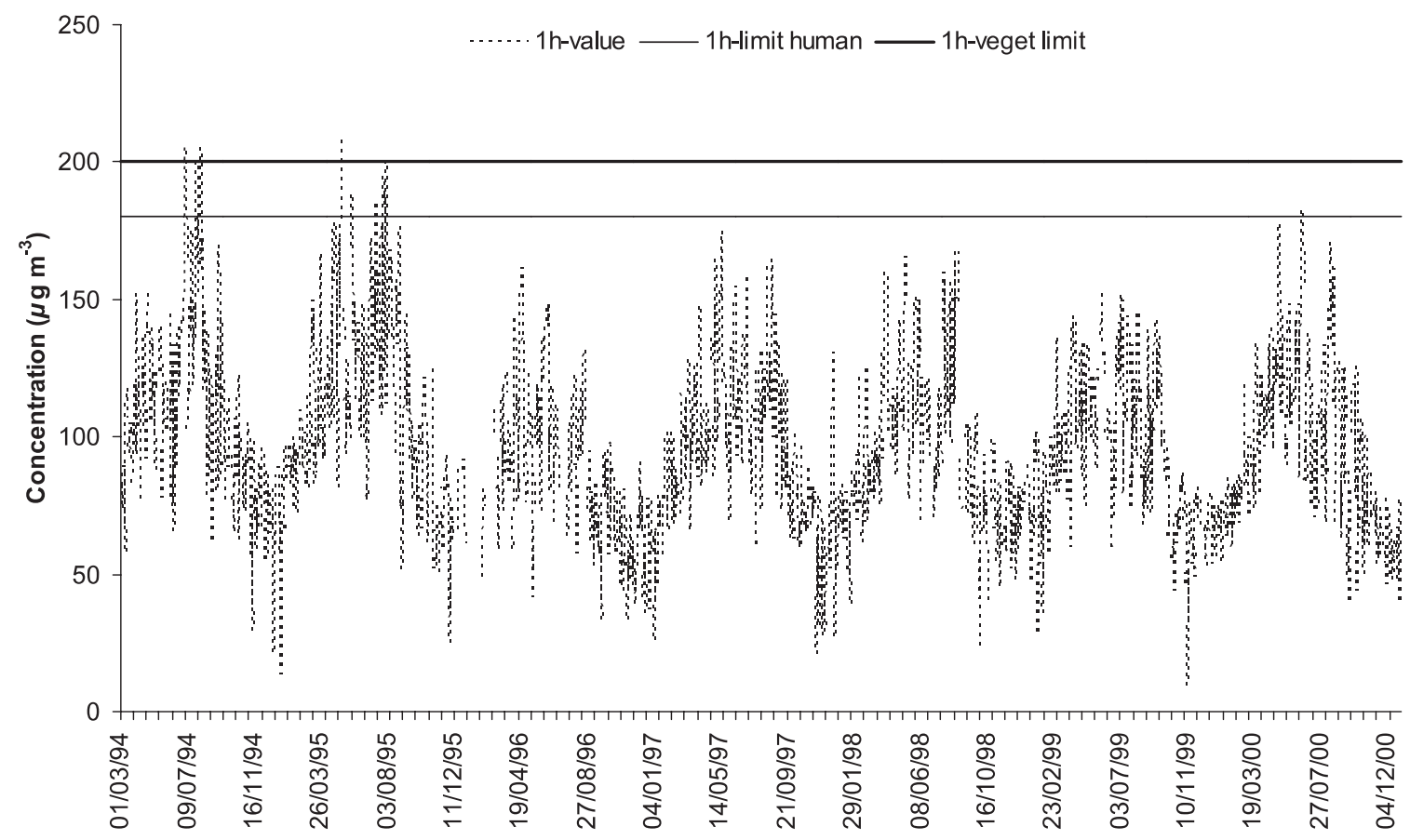

Figure 1. Daily hour ozone concentrations with hour limits at the Bílý Kř́ž station, 1994-2000

Table 2. Observed exceedances of the threshold for information of the public (1-hour concentration higher than $180 \mu \mathrm{g} \mathrm{m}^{-3}$ ) from April to September.

\begin{tabular}{|c|c|c|c|}
\hline Period & $\begin{array}{c}\text { Maximum observed hourly } \\
\text { concentration }\end{array}$ & Date of exceedance & Time of exceedance \\
\hline 1994 & $206 \mu \mathrm{g} \mathrm{m}^{-3}$ & $4^{\text {th }} \mathrm{July}$ & 17.00 \\
\hline 1995 & $210 \mu \mathrm{g} \mathrm{m}^{-3}$ & $6^{\text {th }}$ May & - \\
\hline 1996 & $162 \mu \mathrm{g} \mathrm{m}^{-3}$ & $20^{\text {th }}$ April & - \\
\hline 1997 & $175 \mu \mathrm{g} \mathrm{m}^{-3}$ & $16^{\text {th }}$ May & 11.00 \\
\hline 1998 & $188 \mu \mathrm{g} \mathrm{m}^{-3}$ & $12^{\text {th }}$ August & - \\
\hline 1999 & $153 \mu \mathrm{g} \mathrm{m}^{-3}$ & $28^{\text {th }}$ May & 18.00 \\
\hline 2000 & $183 \mu \mathrm{g} \mathrm{m}^{-3}$ & $22^{\text {th }} \mathrm{June}$ & \\
\hline
\end{tabular}


Table 3. Occurence of exceedances of eight-hour limit for April to September (based on three non-overlapping eight hourly averages between $00.00-08.00,08.00-16.00$ and $16.00-24.00 ; 12.00-20.00 ; 10.00-18.00$ )

\begin{tabular}{|c|c|c|c|c|c|c|}
\hline \multirow[t]{3}{*}{ Period } & \multirow{2}{*}{\multicolumn{2}{|c|}{\begin{tabular}{|c|}
$00.00-08.00,08.00-16.00,16.00-24.00$ \\
$\mu \mathrm{g} \mathrm{m}^{-3}$ \\
\end{tabular}}} & \multirow{2}{*}{\multicolumn{2}{|c|}{$\begin{array}{c}12.00-20.00 \\
\mu \mathrm{g} \mathrm{m}^{-3}\end{array}$}} & \multirow{2}{*}{\multicolumn{2}{|c|}{$\begin{array}{c}10.00-18.00 \\
\mu \mathrm{g} \mathrm{m}^{-3}\end{array}$}} \\
\hline & & & & & & \\
\hline & 120 & 160 & 120 & 160 & 120 & 160 \\
\hline 1994 & 64 & 8 & 62 & 9 & 57 & 8 \\
\hline 1995 & 57 & 6 & 86 & 11 & 84 & 14 \\
\hline 1996 & 8 & - & 15 & - & 15 & - \\
\hline 1997 & 35 & - & 29 & - & 29 & - \\
\hline 1998 & 40 & 3 & 36 & 2 & 39 & 1 \\
\hline 1999 & 36 & - & 32 & - & 34 & - \\
\hline 2000 & 44 & 3 & 44 & 1 & 40 & 1 \\
\hline Sum & 284 & 20 & 304 & 23 & 298 & 24 \\
\hline
\end{tabular}

ues were found on July 1994, on May 1995, on April 1996, on May 1997, on August 1998, on May 1999 and on June 2000 (Table 2). The 1-hour critical level for ozone for the protection of human health, $180 \mu \mathrm{g} \mathrm{m}^{-3}$, was exceeded for 8 days during 1994 and 1995 and one day during 1998 and 2000. In Central Europe, like the Czech Republic, the variation is characterised by a broad summer maximum with high monthly means from May to August (Beck et al., 1998; Hjellbrekke, 2000; Tshiamala and Rožnovský, 2000a, b, c). The onehour limit of $200 \mu \mathrm{g} \mathrm{m}^{-3}$ for the protection of vegetation was exceeded (Table 1) on July and August 1994 (4 days and 4 hours), on May and July 1995 ( 2 days and 2 hours). The highest onehour concentration of ozone in 1998 was also registered at the same month at the other stations throughout the Europe (Beck et al., 1998; Hjellbrekke, 2000).

\section{Eight-hour concentrations}

The current ambient air pollution limit value for human protection is $120 \mu \mathrm{g} \mathrm{m}^{-3}$, the eight-hour mean. The Czech standard of ozone for the protection of human health is $160 \mu \mathrm{g} \mathrm{m}^{-3}$. The considered eight-hour is $00.00-08.00,08.00-16.00$, $16.00-24.00,12.00-20.00$ according to the European stamdard and 10.00-18.00 according to the Czech Standard.

a) Based on three non-overlapping eight hourly averages between $0.00-8.00,8.00-16.00$ and 16.00-24.00:

The eight-hour limit was exceeded for 2.4 to $21 \%$ of cases at the Bílý Kř́ž station. The high- est eight-hour concentrations were registered from April to September for the all measured period and varied from 21.8 to $193.1 \mu \mathrm{g} \mathrm{m}^{-3}$. The high eight-hour values were registered for 64, 57, 8, 35, 40, 36 and 44 days from 1994 to 2000 , respectively. The number of exceedances was of 23 days on July 1994, more than 10 days on April 1994, May, July and August 1995, August 1998, May, June and August 2000. According the Czech standards of $160 \mu \mathrm{g} \mathrm{m}^{-3}$ for human health, we numbered 8, 6 and 3 days when this limit was exceeded in 1994, 1995 and 1998, 2000 at the Bílý Kř́žz station (Table 3).

b) Based on the eight hourly values between 12.00-20.00:

The eight-hour values exceeded the 8-hour limit by $62,86,15,29,36,32$ and 44 days for 1994 to 2000, respectively. The highest ozone concentration was recorded on July 1994, May 1995, April 1996, May 1997, August 1998, May 1999 and June 2000. The Czech limit of $160 \mu \mathrm{g} \mathrm{m}^{-3}$ for human protection was exceeded by 9, 11, 2 days and one day on 1994, 1995, 1998 and 2000, respectively (Table 3 ).

c) Based on the eight hourly according the Czech Republic standards, 10.00-18.00

The eight-hour values exceeded the eighthour limit of $120 \mu \mathrm{g} \mathrm{m}^{-3}$ by $57,84,15,29,39$, 34 and 40 days for 1994 to 2000, respectively. According the Czech republic standards of $160 \mu \mathrm{g} \mathrm{m}^{-3}$ for eight-hour value, this value was exceeded by 8, 14 days and one day in 1994, 1995 and 1998, 2000 (Table 3). 


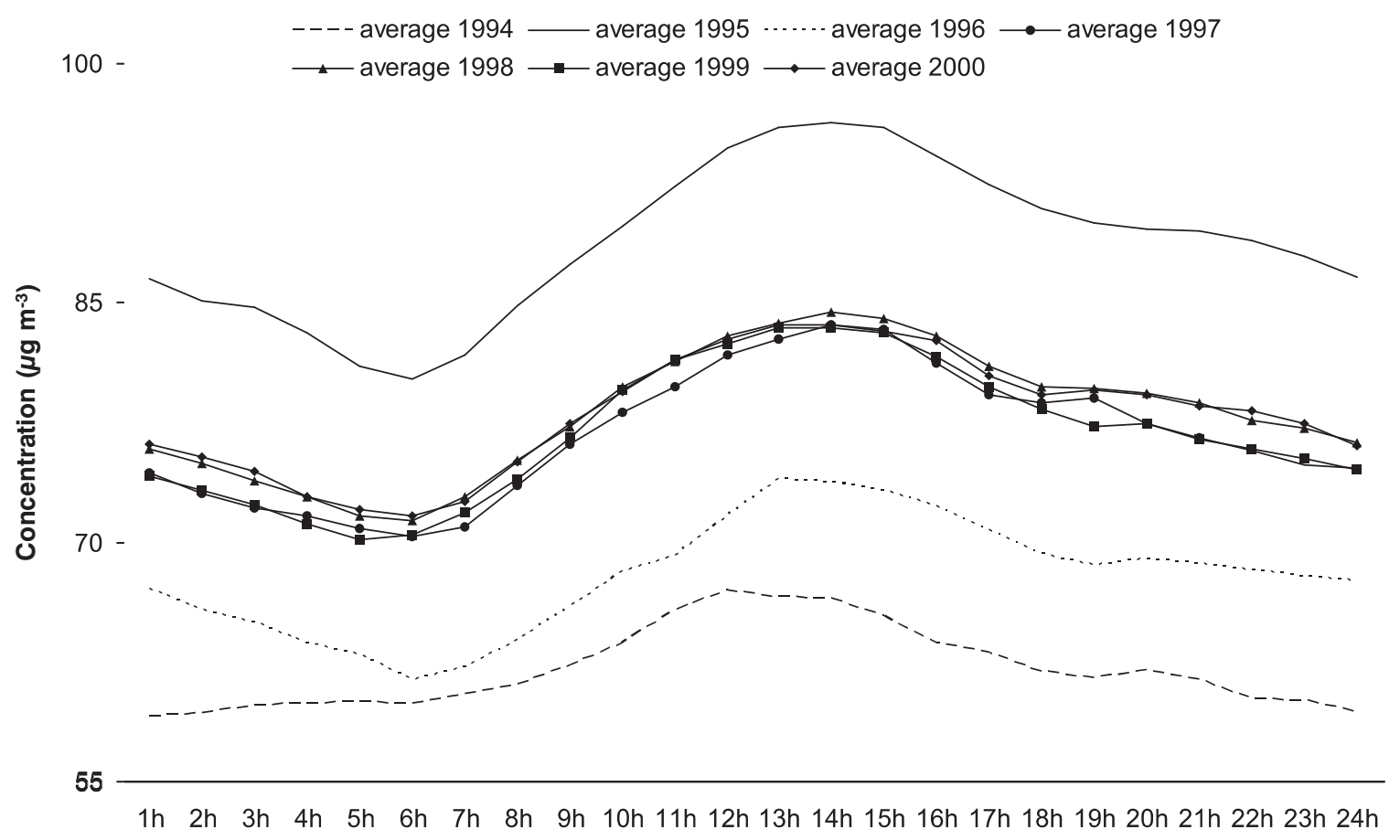

Figure 2. Hourly averages of ozone concentration per year at Bílý Kř́̌ž, 1994-2000

\section{Diurnal values}

In general the lowest concentrations are found in early morning and the highest in the afternoon (Hjellbrekke, 2000). The low concentrations were registered at Bílý Kř́ž between 05.00 and 07.00 (Fig. 2). The high concentrations were found between 11.00 and 20.00 during the summer months. The highest ones were registered on the afternoon and on the evening. The pronounced diurnal peak during the summer months is due to photochemical generation of ozone during daytime as a result of higher temperature and insolation during this time of the day (Hjellbrekke, 2000).

\section{Daily values}

The Bílý Kříž site registered for 1994 to 2000 the daily average of ozone concentration between 5.2 and $173.6 \mu \mathrm{g} \mathrm{m}^{-3}$ (Fig. 3). From 1994 to 2000, the percentage of days when the daily limit of $65 \mu \mathrm{g} \mathrm{m}^{-3}$ was exceeded was 78.4, 71.3, 49.3, 64.4, 69.5, 63.3 and $64.1 \%$ respectively. The highest daily ozone value was found on July 1994, May 1995, April 1996, June 1997, August 1998, April 1999 and June 2000. In warm months from April to September, 100.0, 89.4, 64.6, 89.1, 89.8, 86.8 and $42.5 \%$ of cases exceeded the daily limit from 1994 to 2000 at Bílý Kříž. During cold monts (from December to March), 90.1, 51.0, 39.6, 42.7, 86.8 and $21.6 \%$ of days exceeded the limit of $65 \mu \mathrm{g} \mathrm{m}^{-3}$ from 1994 to 2000.

\section{Seasonal variation}

The concentrations show a clear pattern with maximum values during spring or summer and a minimum in winter. Matyssek and Innes (1999) and Hjellbrekke (2000) describe this situation. The warm months had the high ozone concentrations, it proved that the forest received the high values of ozone from April to September in accordance with Rožnovský and Blažek (1996), APPA (1998), Petružela et al. (1999), Tshiamala and Rožnovský (2000b). The highest monthly ozone concentration from daily averages was on July 1994 and 1995, on June 1996 and 1997, on August 1998, on May 1999 and 2000. With the reference to the monthly concentrations for all period, the peaks were observed on May and July. The highest monthly ozone maximum was found on July (151.8 $\left.\mu \mathrm{g} \mathrm{m}^{-3}\right)$, July $\left(152.9 \mu \mathrm{g} \mathrm{m}^{-3}\right)$, June 1996 (111.3 $\left.\mu \mathrm{g} \mathrm{m}^{-3}\right)$, August $1997\left(122.1 \mu \mathrm{g} \mathrm{m}^{-3}\right)$, August $1998\left(132.9 \mu \mathrm{g} \mathrm{m}^{-3}\right)$, May $1999\left(121.3 \mu \mathrm{g} \mathrm{m}^{-3}\right)$ and May $2000\left(127.5 \mu \mathrm{g} \mathrm{m}^{-3}\right)$ at the Bílý Kř́ž station. 


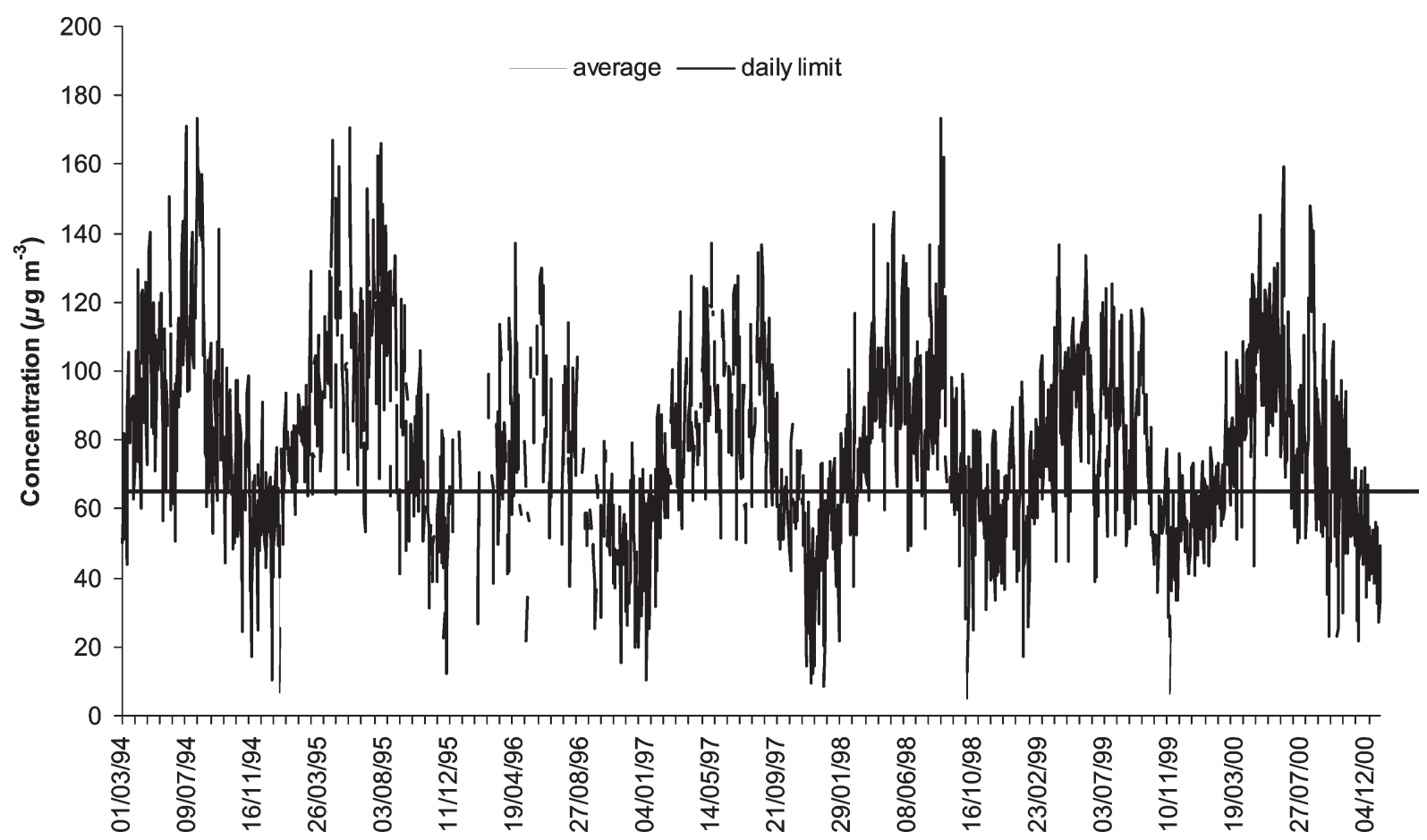

Figure 3. Daily ozone values with daily limit of $65 \mu \mathrm{g} \mathrm{m}^{-3}$ at the Bily Kriz site, 1994-2000

\section{Annual values}

The annual limit for the protection of vegetation is at $40 \mu \mathrm{g} \mathrm{m}^{-3}$. For 1994 to 2000 , the most elevat- ed annual value was observed in 1995 and the lowest one in 1996 (Tshiamala and Rožnovský, 2000a). The years from 1996 to 2000 have regis-

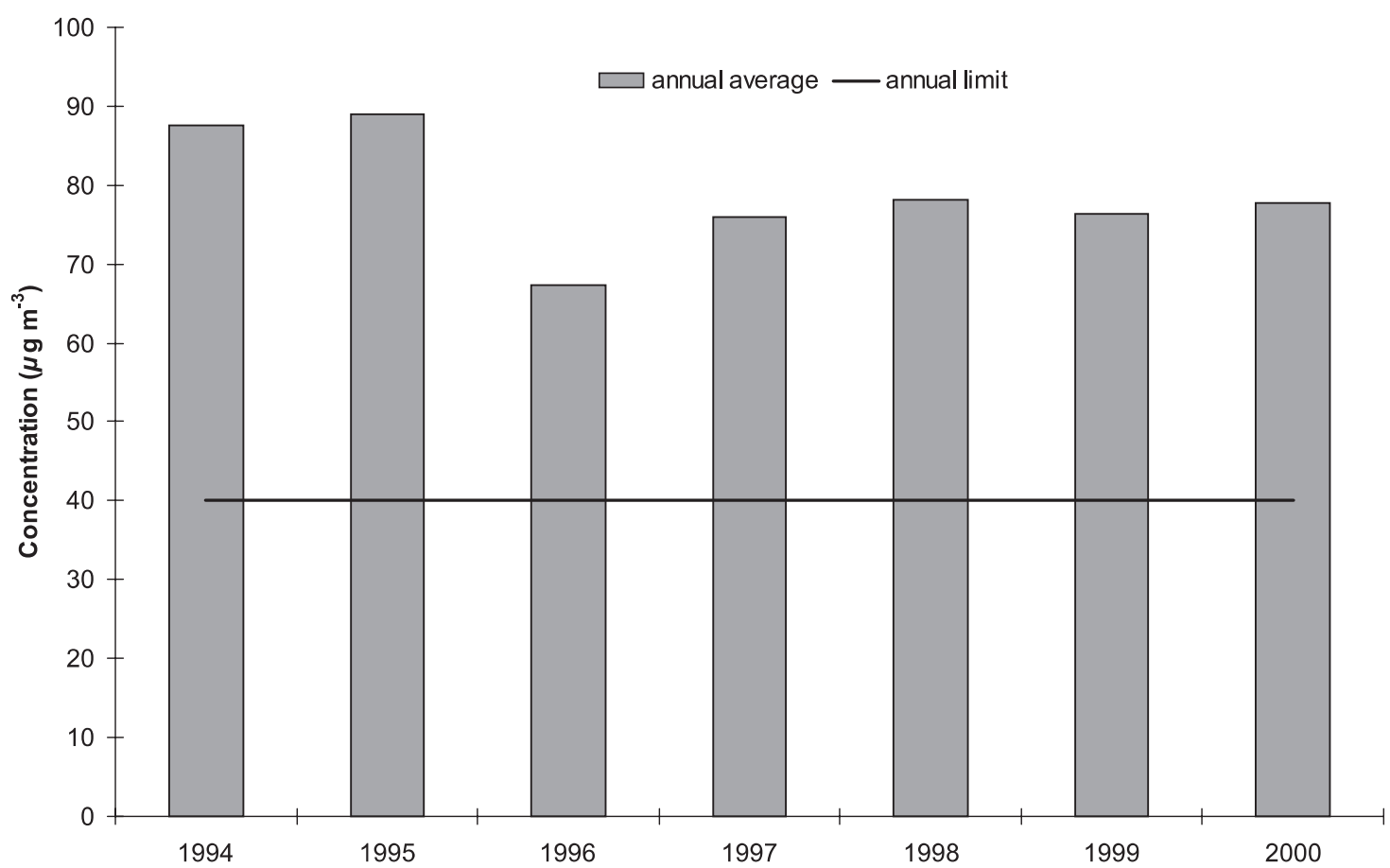

Figure 4. Annual ozone concentrations with annual limit of $40 \mu \mathrm{g} \mathrm{m}^{-3}$ at the Bílý Kř́ž station, 1994-2000 
tered the annual value lower than $80 \mu \mathrm{g} \mathrm{m}^{-3}$ (Tshiamala and Rožnovský, 2000b). The annual values for other years have been more than twice higher than the annual limit of $40 \mu \mathrm{g} \mathrm{m}^{-3}$ (Fig. 4). From 1994 to 2000 the highest annual ozone concentration was of $88.9 \mu \mathrm{g} \mathrm{m}^{-3}$ in 1995. Figure 4 shows that from 1994 to 2000 the annual ozone values fluctuated between 67.4 and $88.9 \mu \mathrm{g} \mathrm{m}^{-3}$. The increase from 1996 to 1998 was found through the Czech Republic for the same time (Petružela et al., 1999; Tshiamala and Rožnovský, 2000a, b) and through Europe (Beck et al., 1998; Závodská et al., 1998; Molnárová and Mindaš, 1999; Hjellbrekke, 2000).

\section{CONCLUSION}

Studies made in the Bílý Krríž station found that the concentration of ozone in this area is markedly higher from the levels generally accepted as natural. The highest monthly ozone concentration in the region of Beskids occurred in July and in the beginning of August. But the tropospheric ozone presently increased markedly, especially from 1996 at the Bílý Kříž station. The all critical indexes for ozone are exceeded considerably for the considered period. The human health, material and forest such us vegetation were markedly damaged by tropospheric ozone at the Bílý Kříž station, in the regin of Beskids.

\section{REFERENCES}

Andreani-Aksoyoglu, S. (1996). Impacts of air pollutants on ecosystems: a review. Comprehensive assessment of energy systems (GaBE) / Air pollution. PSI Bericht Nr. 96-05, Paul Scherrer Institut, Switzerland, 64 p.

APPA (1998). La pollution de l'air: sources, effets, prevention. Association pour la Prevention de la Pollution Atmospherique/ Ville de Besancon - Service Hygiene Sante.France, 82 p.

Beck, J.P., Krzyzanowski, M. and Koffi, B. (1998). Tropospheric Ozone in the European Union "The Consolidated Report”, European Commission Brussels. Topic report no. 8/1998. http://www.eea.eu.int

de Leeuw, F., Sluyter, R. and Camu, A. (2000). Air Pollution by Ozone in Europe in 1998 and Summer 1999. Topic report No 10/2000. European Environment Agency, Copenhagen. http://www.eea.eu.int/

de Leeuw F., Sluyter R. and de Paus T. (1999). Air pollution by ozone in 1997 and summer 1998. Topic Report no. 03/1999 - European Topic Centre on Air Quality. EEA, Copenhagen. http:/www.eea.eu.int

EEA (1997). Air pollution in Europe. Edited by A. Jol and G. Kielland. European Environment Agency, Copenhagen, $107 \mathrm{p}$.

EEA (1998). Tropospheric ozone in EU- "The Consolidated Report". Topic Report 8/98 ETC/AQ. http://www.eea.eu.int/

Fally, S., Joannes, D., Leduc, D. and Scharll, M.-F. (1995). La pollution, ses effets et ses coûts en region de Bruxelles-capitale. Universite Libre de Bruxelles, Belgique, 67 p.

Hjellbrekker, A.-G. (2000). Ozone measurements 1998. EMEP Co-operative Programme for Monitoring and Evaluation of the Long-range Transmission of Air Pollutants in Europe. EMEP/CCC - Report 5 / 2000. http://www.nilu.no/projects/ccc/index.html

Hůnová, I., Livorová, H. and Ostanická, J. (2000). Critical levels for ozone in the Czech Republic. Meteorological Journal, 3, 11-18.

IFEN, (1999). The environment in France. French Institute for the Environment, Orleans, 316 p.

IMIP (1999). Prague - Environment 1998, Yearbook, March 1999, 154 p.

Jackson, D.M., Rufty, T.W., Heagle, A.S., Severson, R.F. and Eckel, R.V.W. (2000). Survival and development of tobacco hornworm larvae on tobacco plants grown under elevated levels of ozone. Journal of Chemical Ecology, 26, 1-19.

Matyssek, R. and Innes, J.L. (1999). Ozone - A Risk Factor for Trees and Forests in Europe? Water, Air and Soil Pollution, 116, 199-226.

Molnárová, H. (2000). Vertical gradient of tropospheric ozone concentrations in region of Polana Mts. and Zvolen basin. Meteorological Journal, 3, 25-33.

Molnárová, H., Mindáš, J. (1999). Výsledky merania koncentrácií ozonu voblasti BR Polána (Results of ozone concentration in the region of Polana). In OVZDUŠlí99, Masaryková Univerzita, Brno, February 7 -10, 1999, 73-76.

Pelikán, E., Eben, K., Vondraček, J., Krejčír, P. and Keder, J. (2000). Ground level ozone peak forecats using neural networks and kalman filter. Meteorological Journal, 3, 3-8.

Petružela, L., Lízner, M., Lippert, E. and Řenčová, L. (1999). Zpráva o životním protředí Česke republiky vroce 1998 (Report on environment in the Czech Republic in 1998). Ministerstvo životního prostředí (Ministry of Environment), Praha (Prague), 9-18. 
Polle, A., Matyssek, R., Gunthardt-Georg, M.S. and Maurer, S. (2000). Chapter 12. Defense Strategies against Ozone in trees: The Role of Nutrition. In AGRAWAL S.B., AGRAWAL M. (Eds.), Environmental Pollution and Plant Responses. Lewis Publishers, 223-245.

Rožnovský, J. and Blážek, Z. (1996). The Variability of Ozone Concentrations in the Region of Bílý Kř́ž. In: Meteorological Processes in the Boundary Layer of the Atmosphere. Bratislava, Geophysical Institute of the Slovak Academy of Sciences, 58-63.

Svoboda, J., (2000). Měření ozonu analyzátorem 41 M-LCD (Ozone measurements using the 41 M-LCD analyser). In: XXIII. Medzinárodná vedecká konferencia "Bioklimatologia a Zivotné Prostredie", 12-14 September 2000, Košice (In 23th International Conference "Bioclimatology and Environment", 12-14 September 2000, Kosice). CD-ROM

Tshiamala Mbuyi, M.-H. and Rožnovský, J. (2000a). Proměnlivost koncentrací ozonu v oblasti Bileho Krize v letech 1996 až 1998 (The variability of ozone concentrations in the region of Bílý Kříž in years 19961998. In Zpravodaj Beskydy (The Beskids Bulletin) 13, 57-62.

Tshiamala Mbuyi, M.-H. and Rožnovský, J. (2000b). Hodnoceni koncentraci troposferickeho ozonu na Bilem Krize ve letech 1996-1999 (Evaluation of tropospheric ozone at Bílý Křriž for 1996-1999). In Lesni ekosystemy vměnicich se růstových podminkách (In Forest ecosystems in change with growth conditions), Ostravice 9.-12.10.2000.

Tshiamala Mbuyi, M.-H. and Rožnovský, J. (2000c). Ozone assessment at Bílý Kř̌ž in the Czech Republic for 1995-1998. In 25th Conference at Nice 25-29 April, 2000, Geophysical Research Abstract, Volume 2, 25th General Assembly. CD-ROM 1029-7006.

Závodská, E., Závodský, D. and Kremler, M. (1998). Exposure of surface ozone in Slovakia, 1992-1996. In Hurtalová T. (Eds.): Contribution of the Geophysical Institute of Slovak Academy of Sciences. Sciences of Meteorology, 18, 19-30. 